\title{
FORMS OF TERRORISM IN ANCIENT ROME
}

\author{
Mădălina STRECHIE \\ University of Craiova, Romania \\ madalinastrechie@gmail.com
}

\begin{abstract}
Terrorism is an old phenomenon in human civilization. Terminologically, it comes from Latin, but this scourge also fully manifested itself in Roman civilization, throughout its history. This study seeks to fill a bibliographic gap on this criminal phenomenon, most studies of it starting with the Middle Ages, without any reference to Ancient Rome, which is unfair, especially since Rome was confronted with this phenomenon, which it defined terminologically and to which it responded with the necessary force, thus transforming its defence policy.

The first forms of terrorism emerged in Rome during the Kingdom, when, at the beginning of its political organization, Rome faced numerous terrorist manifestations, especially from outside the Roman state. The Gauls were, at the beginning of the Republic, genuine agents of terrorism in Rome through their plundering expeditions that caused real terror. Etruscan pirates were terrorists, too, for the Roman trade, the struggle of the plebeians and their withdrawal with barricades in order to obtain political rights meant real political terror at that time, then Spartacus' revolt and his march which spread terror throughout Rome, the civil wars which bled Rome became genuine forms of internal terrorism, especially because of the assassination of Roman state leaders, as well as the corruption masterly unmasked by Cicero.

The forms of external terrorism were also present, the most notorious episode being the Punic wars, in particular the war of Hannibal, the most effective terrorist for Rome, the Dacians' plundering expeditions in the Roman garrisons in Moesia, the battles with the Parthians and the Britons are as many forms of the terrorism that Rome faced during its history, which compelled it into creating new forces capable of responding to this new way of fighting. We believe that the Praetorian Guard, with all its units, was the most effective counter-terrorist force in combating the terrorist phenomenon strongly manifested in Rome. Therefore Rome, knowing the phenomenon, defined it most precisely, a definition that still applies today.
\end{abstract}

Key-words: Ancient Rome, terrorism, counter-terrorism, essential terminology, attacks.

\section{Introduction}

Terrorism has been, over the course of history, a violent phenomenon which ancient civilizations, especially the Eternal City, Rome, faced. From a bibliographic point of view, the subject of ancient terrorism is either marginally treated or not mentioned at all, the main works devoted to its study beginning with the study of the phenomenon in the Middle Ages, in the happiest case, but most of them approach the modern period phenomenon.

Our study deals with some forms of terrorism that ancient Rome faced during its history. Moreover, it is Rome that defined the phenomenon, while confronting it, the Roman definition still existing today in point of form and especially of content. Terrorism fully manifested itself in ancient Rome, both internally and through external agents/enemies of the Roman state, 
regardless of the stage of the Roman state's history. Therefore, Rome had to oppose a force capable of combating terrorism, the Roman army being also adapted as a counter-terrorist force, in particular through what was called the Praetorian Guard, but not only. Roman counter-terrorism was performed not only through effective military battles, but also through informative, political and diplomatic methods, as the Romans were the ones who successfully used information to combat terrorist forces, wherever they were, whether internal or external, since Rome also defined the concept of information.

\section{Terminological issues. History of a word - history of a phenomenon}

The definition of terrorism in different sciences is based on extreme violence, which has an emotional impact on the community. Thus we have selected for this study the following definitions: the sociological definition: "a political strategy whose principle is based on the systematic use of acts of violence for the propagation of insecurity." [1]; the military definition: " $a$ method that inspires anxiety through violent action." [2]; the politological definition: "It is a strategy that is essentially based on the psychological impact." [3]The Roman definition of the term is the most complex and complete (it is not accidentally that the etymology of the modern word is Latin), which relies on the psychological impact. The Latin verbs from which the term terrorism originates are the following: Terrifico, -are, -avi, -atumt.v.Ito scare, to terrify; it occurs in Lucretius' work; terrificomentes $=$ to terrify the mind, also in Vergilterrificoanimos $=$ to terrify the souls;Terreo, -ere, -ui, -itumt.v. II.1. to scare, to terrify; to frighten; 2 (rarely) to make somebody run, to chase, to drive away; 3. to prevent out of fear, to stop;Territo, -are, -avi, -atumt.v.I.to scare, to terrify (it occurs in Caesar's work).[4]There are also nouns from these verbs: terrificatio, -onis f.fear, terror; terriculamentum, -ii n. scarecrow, spectrum, ghost; territio, -onisf. fright and the most complete terror, -orism. 1. fear, terror (terrorem alicuifacere $=$ to strike terror into smb's breast); terrorihostibusesse=to be an object of fear for the enemies-in Caesar's work); 2. (fig.) that causes terror: 3. terrifying news (rumour); 4. terrifying event.[5]So in the Latin language terror meant something that caused extreme, paroxysmal fear, a very strong feeling of fear of death, especially since there was another term to express fear in Latin, but to a lesser degree, such as the verb metuo, -ere, -ui, -itumi.v. and t.v. II.to be afraid, to fear, to be worried, to fear an accusation, to fear a danger; metus, -us, $\mathbf{m}$. 1. the act of fearing (what might be), fear, worry, hesitation, fear of the gods, fear of the enemies - metushostilis, in Sallustius' work.[6]

Terrorism in the Roman vision was a phenomenon with a strong emotional impact on the Romans, a terror involving the disappearance of the Roman state, of the safety and security of the community and of the Roman citizen, followed by an imminent, violent, tragic death, without any possibility for the Roman community to escape, or the impossibility of honourable death, in the case of the Roman military (which was fully manifested during the Punic Wars, when most of the military forming the Roman headquarters lost their lives at Cannae and Trasimene, the Roman victims being counted by the enemies through cutting their fingers with the sign of the officer's rank, namely the golden ring, and according to Roman historical sources there were more than 10,000 Roman officers who perished in these two Roman-Punic confrontations), a feeling which rapidly propagated over the collective Roman mind (terror was also boosted by rumour, rumorin Latin) and created a paroxysmal phobia of the community, suppressing its famous pragmatism, paralyzing all its rational actions for a certain period of time. 


\section{Forms of internal terrorism}

Ever since the royal period Rome was shaken by terrible fears that paralyzed Roman society. In the category of paroxysmal fears that shook the Roman community, through the sense of the Roman state's disappearance, there were many political actions, especially coups. Thus, the penultimate Etruscan king, Servius Tullius, is assassinated and a coupis given in full, and foreign aid is required (Etruscan, by Tarquinius, the usurper of the throne), which involved the Roman state in a war with the Etruscans, very strong commercially and financially, as they dominated the ports of Italy. Tarquinius Superbus (Tarquin the Proud) assassinated the rightful king, Servius Tullius, and led a veritable campaign of misinformation and manipulation spreading "the rumour that the king is ruling against the people", he uses traffic of influence and corruption, "he lures the young people with all kinds of gifts; and thus he increases his influence either by promising the moon or by blaming the king openly. Finally, when he found it appropriate to start, accompanied by a host of armed followers, Tarquinius dashed into the forum" [7].

The abusive leadership of Tarquinius Superbus ends the same as it started, through a coup d'état that turns Rome from a monarchy into a Republic. It is also a form of violent action, especially since the Roman army played a predominant part in expelling the last Etruscan king, who however asked for the help of the Etruscans led by Porsena, all this leading to the siege of Rome, which made the Romans be terrified of the possibility of losing the state: "The Roman Senate had never been terribly panic-stricken until then ... the senators were afraid not only of the Etruscans, their new enemies, but also of their own fellow citizens ... the plebeians" [8].

The Romans had to struggle hard with the Etruscans, as the Roman army was not a professional force at the time, but had patriotic commanders who, through individual and collective heroism, won the cause for the Romans.

The Samnites, "a powerful people both because of wealth and weapons", also terrorized Rome within the Italian Peninsula. The anti-terrorist key found by the Romans in this episode were the singular heroes such as Valerius Corvus, the military tribune Publius Decius, the consul Decius Mus, and the dictator Papirius [9]. Dictatorship appears as a saving magistracy of Rome, an extreme one, as well as the terrorist acts that it was supposed to manage. It had a time limit of 6 months because it held all the powers of Roman democracy, including the supreme military command, the dictator being seconded by magister equitum $=$ the cavalry commander. The dictatorship magistracy was the solution that solved many forms of terrorism in Rome, either internal or external.

Another episode of internal terrorism suffered by the Romans was at the beginning of the Republic through the plebeian issue, which constituted a complex social, civil, political and economic phenomenon for Rome. Thus, this form of terrorism arose, as the Roman historian Titus Livius tells us, out of the "hatred between patricians and plebeians" because of some "inner discord" existing within Roman society, and the plebeians' refusal to enlist in the wars of the Romans with the Etruscans caused "a more terrible panic" besides the "internal worries and troubles". The plebeians decide to retreat onto the Sacred Mountain of Rome, entering into a kind of strike and anarchy, after the numerous assassinations of those who wanted reforms for the plebs, the result was that "Rome was overwhelmed with panic" [10]. Rome settles the disputes with the plebeians by granting civil and political rights, namely the right to have two magistrates representing their interests, tribuniplebis, as the most effective Roman method to combat domestic terrorism, namely to share power and the benefits of the Roman community with those who were 
dissatisfied, to integrate them into its system, of course where it could be done.

The case of the revolted slaves was the most violent and terrible form of domestic terrorism that Rome faced, but it defeated it with equally terrible violence, similar to the emotional impact produced. The first revolt of the slaves was led by Herdonius, who caused "awesome fears" in the Roman community[11], the second and most striking being Spartacus' march. He was a famous gladiator, endowed with a weaponry talent, accustomed to the unconventional fight, in small, crowded spaces, which brought him many victories in front of the Roman armies used to the open field fights. Many other slaves, originating from different regions of Italy, joined the march, a fact which represented a genuine economic terrorism for Rome, whose economic production relied on the slaves' labour, but also of the chaos of the entertainment industry, the gladiators being a very important link in the maintenance of public opinion by the Roman state. The emotional shock was terrible for the Romans, because it was not only the fear caused by the slaves' revolt, but also the humiliation related to the defeat of the Roman citizens' armies by some all ogeneous slaves, some belonging to peoples who were the enemies of the Romans. Rome sent two generals, Crassus and Pompey, to defeat this army of slaves. They won the victory of the Romans, yet not easily [12]. But the violence of the Romans was extreme, they crucified and posted the crucified along Via Appia, the longest road to Rome, to prove that Roman pride could not be defeated. To terrorism they responded with terrorism, but the Romans learnt from the defeats before Spartacus and reformed the army, setting up new units, we could even call them anti-terrorist units because they were able to fight in cities, in small spaces, a kind of troops of intervention between gendarmerie and commando troops. Rome was also bled by political assassinations, corruption for the purchase of positions, political plots supported by foreigners, and abusive and illicit accumulation of money intended for the Roman treasury (state budget), terrorist acts that were sometimes inspired by ideology. Thus, Optimates were the conservatives, the representatives of traditionalism, the great landowners of Rome and Populares, the progressists, the representatives of the new people, those who were mostly from ordo equester and who relied on personal merits and financial capital. This group of interests was also supported by the plebeians, whose magistrates were often murdered by order of Optimates.

Rome was also bled by political assassinations, corruption for the purchase of positions, political plots supported by foreigners, and abusive and illicit accumulation of money intended for the Roman treasury (state budget), terrorist acts that were sometimes inspired by ideology. Thus, Optimates were the conservatives, the representatives of traditionalism, the great landowners of Rome and Populares, the progressists, the representatives of the new people, those who were mostly from ordo equester and who relied on personal merits and financial capital. This group of interests was also supported by the plebeians, whose magistrates were often murdered by order of Optimates.

Cicero revealed many such plots and abuses, political assassinations, true acts of terrorism, treason, and collaborations with the enemies of the Romans (such as Catilina's plot and unprecedented abuse, an economic terrorism by Verres) [13], the great Latin classic being himself the victim of a political assassination.

Pompey remains in Roman history with the cognomen of Magnus (the Great) after defeating the economic terrorists from the Roman seas, the Etruscan pirates, those who "endangered the grain supplies of Rome", that is why he was invested with an impressive army force of "20 legions and a fleet of 500 vessels", having "imperium infinitum" [14], to physically eliminate these Etruscan pirates, who threatened the food 
security of the Roman people and all the Roman maritime trade.

The most terrible forms of internal terrorism in ancient Rome were the civil wars, (with ideological sources confronting the two groups of interests mentioned above), because Roman anti-terrorist forces, namely the Roman legions, faced each other for political supremacy. Again, there is a change of the Roman state, which, following the three civil wars, turns from a Republic into an Empire. The one who began terrorist hostilities was Sulla, who launched the first civil war through a "coup d'état" proclaiming himself a dictator, which no longer respected the Roman salvation magistracy, but was "an exceptional, personal power", triggering "terrible collective reprisals and individual assassinations" [15]. So, Sulla was a terrorist by the manner of expressing his will and by using legions as troops for the assassination of political rivals, which spread terror in the Roman community.

Caesar was next by crossing the Rubicon with his legions forged in the 10 years of wars with the Gauls, the siege of Rome, then the bloody confrontations between him and Pompey, as well as the collateral victims of this war. Although they were allies in the first triumvirate, the two generals, Pompey and Caesar, came to be the actors of a political, terrorist act, one wanted to maintain a system, the other wanted to form a new system. Both looked like two enemies at each other, so Caesar organized the triumph after defeating the Roman citizens of Pompey, an unimaginable fact, and in the Roman provinces, loyal to Pompey, he proved cruel [16], so his armed revolution had all the ingredients of a terrorist act. His assassination by Pompeian reactive groups continued the terrorist chaos in Rome, his physical suppression taking place in the temple of the Roman laws, the symbol of the Roman state, namely in the Senate of Rome. The second civil war ends with another civil war, another terrorist act that disturbed the Roman state from inside, being also prepared by a triumvirate of the future main combatants, Antonius and Octavianus, the future Augustus. After violent episodes involving the loss of Roman lives, Augustus wins, giving a constitutional blow and assuming "unlimited auctoritas", that "power arising out of respect and prestige" [17].Augustus, paradoxically, is the one who stopped for a long time the terrorist acts in Rome, because he used the army to maintain the internal order, which was possible by holding imperium (with the meaning of supreme military command) throughout the imperial territory, and this was "the secret of Augustus" [18].

\section{Forms of external terrorism}

Rome faced many enemies throughout its existence, which made it wary of anyone who was not its citizen, hence the expression Hospes, hostis (est) = The guest is an enemy. In its history, many enemies endangered its statehood, the life of the community of its citizens, who were terrified by the violence and power with which these enemies had invaded the Roman territory.

The Gauls were the first to make a real "invasion" with the purpose of plundering, but also of suppressing the security, the safety and physical and legal integrity of any Roman citizen, Rome facing a "more terrible danger than ever", especially because the Eternal City became, after this Gallic invasion, "the city full of enemies, who were teeming in the streets."[19]As the Gauls overwhelmed the Romans, they were able to negotiate with them, using blackmail and demanding the redemption of Roman citizens in gold, by using fake scales and counterfeited weights, including the sword of the Gallic leader, Brennus, hence the Latin expression Vaevictis! = Woe to the conquered. This slap on the cheek of Roman pride would be fully paid by Caesar, who abolished once and for all the Gallic danger by conquering the whole Gaul.

Another terrorist episode with invading external forces was the war with Pyrrhus, the king of Epirus, who at the Caudine Forks, 
with his army "downed the Roman pride and stubbornness", which constituted "a terrible disaster"[20]for the Roman community, especially as Rome fought for its allies. Here, although it was rather a draw game between Pyrrhus and Rome, the Romans were humiliated, the senators and the leaders of the army being put in the yoke, the impact and value of the symbol being much more painful for the existence of the Roman state than the military losses themselves.

The Carthaginians were those who exerted a secular terror on the Romans, especially since the period of the Punic wars spread over the years 264-146 B.C., profoundly harming not only the Roman army, almost eliminated by the Cannae and Trasimene disasters, but also the entire defenceless community in Rome, with only children and elderly people who took their own lives in order not to get into the hands of the enemy, famous for its cruelty, by the expression crudelitasquampunica. Only one man was able to put the entire Roman state into the balance, Hannibal, so the last of the three Punic wars was called the war of Hannibal. The war with Hannibal was an anti-terrorist war, because the existence of the entire Roman state depended on it, Hannibal ante portas = Hannibal is in front of the gates (of the city of Rome), it was the time that "caused tremendous fear and disorder among the people"[21]. Hannibal's "operational purpose... was to defeat the army so categorically... the cohesion power of Rome.'[22]

The Dacians and their expeditions for the plundering of the Roman provinces caused terror among the Roman citizens in the provinces where the attacks of outrageous violence were sent out, expeditions described by Ovid, the poet of love exiled at Pontus Euxinus [23]. The poet is terrorized by these expeditions and by the way in which they were made, only in winter, in terrible, frosty weather, always having a devastating effect on Roman outposts.

Rome was also familiar with religious fanaticism, especially that coming from the
East, as there were many clandestine Egyptian, Persian and Christian cults on the Roman territory, all of them representing security issues for the Romans, in their early stages.

Externally, the Romans also engaged in unconventional fights with the Parthians, who were never defeated by the great Roman Empire, through their harassing struggle, with small effective forces, which caused great losses among the Romans and maintained a sense of great fear in the Roman community.

\section{Roman anti-terrorist forces}

Whether they came from within, or they came from outside, Rome found the necessary forces to oppose, combat, and even eliminate the forms of terrorism it faced. Thus, inside, it mostly used institutions such as dictatorship, an extreme magistracy under extreme conditions, the plebeian tribunal, a magistracy which attracted the plebeians to the power and the Roman state, the consulate, the ordinary magistracy with the widest range of prerogatives during the Republican period, capable of combating corruption, political plots and economic disasters, as well as the Princeps of the Imperial era, who was both a dictator, a tribune of the plebs, and the supreme consul and supreme imperator.

An effective method of combating especially external terrorism was the foreign policy, and Rome used "alliances" and "annexes" to eliminate external danger by setting up a sort of Roman "protectorate" with the phrase "socius et amicus" [24] = ally and friend. Rome thus stopped the terrorist threat, all roads led to Rome, but not of those who produced terror in its city. Thus, it did not hesitate to nominate loyalists in some kingdoms with potential terrorist danger to the Romans, or simply to eliminate the problem leaders or to annex their countries through military campaigns, as was the case with the Punic empire, that of Gaul, Dacia, etc.

Romanization, following foreign policy and consisting in the integration of the 
conquered and their transformation into Romans, was the most important antiterrorist force that acted in the long run and was never defeated by any terrorist force.

The law was also a good anti-terrorist means, with Rome mostly legalizing some religious cults or offering civil and political rights to certain social categories in order to ensure internal security.

The army was the best anti-terrorist force that Rome sent every time to face terror, both internally and externally. Through its army, Rome imposed "the imperialism of the city", as Eugen Cizek said, moreover, this army was "tempered in previous wars, therefore it was able to bear, in good conditions, any major shock."[25] There were more major shocks for the Roman army. The most important was the Spartacus episode, which forced it to form units capable of fighting in cities, with techniques adapted to the gladiators' fight.

Another shock was represented by civil wars, when the army was used by politicians. Augustus is the one who shocked the Roman army most, but in a way that would not harm it. Augustus shared politics with the army, especially the executive, the army becoming the government of the Roman Empire, with forces capable of maintaining internal security within the boundaries of the whole empire. Moreover, elite units are formed, the Praetorian Guard, Praefectura Praetorii [26] , with all its services, became a genuine Secret Service of Rome, which prevented any form of terrorism through its subunits (in particular, through the extraordinary troops of equities singulars, secret agents, polyvalent in point of military training, considered the "cavalry wing of the Praetorian Guard [27], whose weapon was different depending on the enemy they faced, the best of the best, who were sent to other kingdoms for coups, for the imposition of Roman interests or the killing of the Romans' enemies wherever they were). The Roman army also controlled all the services that pertained to Roman security, while promoting the principle of the prevention of terrorism, rather than the open struggle with them: food, through Preaefectura Annonae = the supply service; communications, thepost, Praefectura a vehiculis $=$ Roman postal service and control of land transport routes; the control of foreigners in Rome, but also the population movements through Praefectura Urbi; the safety of the citizens, markets and fire extinguishing (a kind of ISU), namely Praefecturavigilum; the managing of finances through publicani. The Praetorian Guard also had a legal role, especially as the great jurists of Rome during the Principate were the commanders of the Praetorian Guard.

Augustus is the one who forged the Roman army as an anti-terrorist force, the army of his time comprising 30 legions that maintained Pax Augusta, which later became Pax Romana, in fact a period of security of the Roman state, regardless of its borders, security ensuring unprecedented prosperity and the integration of non-Romans through Romanization.

\section{Conclusions}

Rome faced various forms of terrorism and retaliated against it with all the means it had, especially with its army, one of the most efficient armies in the world. The definition of terrorism was given by Rome, because Rome was the first major civilization that faced this phenomenon. Rome opposed with its existing forces, the army, or invented others such as information, which etymologically comes from Latin, informo, are, -avi, -atumt.v. I.1 to make by giving a form, to create, to form, to give rise; 2. (fig) to form; 3. to represent, to figure, to express, to describe; 4. to think of an idea (a notion), to conceive [28] and informatio, -oinisf.1. sketch, plan, drawing;2.idea, notion, representation, image;3information, cultivation, instruction [29]. The information in which the army and politics had a dominant role was the anti-terrorist plan of Rome. 


\section{References}

[1]***Larousse. Dicționar de sociologie, Traducere de Maria Țuţuianu, București, Editura Univers Enciclopedic, 1996, p. 298.

[2] Apud Olga Dănilă, Visarion Neagoe, Terorismul, o abordare psiho-sociologică, București, EdituraMilitară, 2011, p. 21.

[3] Cf. Gérard Chaliand, Arnaud Blin (coord.), Istoria terorismului din Antichitate până la Daesh, Traducere de Giuliano Sfichi, Iași, EdituraPolirom, 2018, p. 34.

[4] Apud Gheorghe Guțu, Dicționar Latin-Român, Ediția a II-a revăzută și adăugită, București, Editura Humanitas, 2003, pp. 1327-1328.

[5] Ibidem.

[6] Ibidem, p. 821.

[7] Titus Livius, Ab Urbe Condita (De la fundarea Romei), Traducere, tabel cronologic și note de Paul Popescu Găleșanu, București, Editura Minerva, 1976, p. 61, p. 63.

[8] Ibidem, p. 85.

[9] Ibidem, p. 280, p. 292, p. 307.

[10] Ibidem, p. 97, p. 101, p. 116, p. 127.

[11] Ibidem, p. 135.

[12] Marcel Bordet, Istoria Romei antice, Traducere: Maria Ivănescu, București, Editura Lider, noyear, pp. 159-160.

[13] Marcus Tullius Cicero, Operealese, volumul I, ediţie îngrijită de G. Guţu. Bucureşti, Editura Univers, 1973.

[14] Romulus Gidro, Aurelia Gidro, Roma antică. O istorie pentru toți, București, Editura Neverland, 2018, pp. 183-191.

[15] Ibidem, pp. 183-191.

[16] Cf. Luciano Canfora, Iulius Caesar, dictatorul democrat, Traducere de Radu Gâdei, București, Editura All, 2008, pp. 258-262.

[17] Philip Matyszak, Dușmanii Romei de la Hannibal la Attila, Traducere de Gabriel Tudor, București, Editura All, 2008, p. 150.

[18] Pierre Grimal, Secolul lui Augustus, Traducere, note și prefață de Florica Mihut,, București, Editura Corint, 2002, p. 57.

[19] Titus Livius, op. cit., pp. 246, 229.

[20] Ibidem, p. 336, p. 337.

[21] Ibidem, p. 83.

[22] Nigel Bagnall, Războaiele punice 274-146 î. Hr., Traducere din limba engleză Teodora Nicolau, București, Editura Litera, 2018, p. 75.

[23] See Ovidius, Publius, Naso, Opere, Coord. Andrei Ţurcanu, Chişinău, Editura Gunivas, 2001.

[24] Cf. M. Cary, H. H. Scullard, Istoria Romei până la domnia lui Constantin, Ediţia a III-a, Traducere de Simona Ceaușu, București, Editura All, 2008, pp. 196-199.

[25] Eugen Cizek, Istoria Romei, București, Editura Paideia, 2002, p. 104, 105, 103.

[26] ***Larousse. Dicționar de civilizație romană, Traducere de Șerban Velescu, București, Editura Univers Enciclopedic, 2000.

[27] Adrian Goldsworthy, Totul despre armata romană, Traducere Liana Stan, București, Editura Enciclopedia Rao, 2008, p. 58.

[28] Gh. Guțu, op. cit., p. 674.

[29] Ibidem, p. 675. 